\title{
Anvil microphysical signatures associated with lightning-produced $\mathrm{NO}_{x}$
}

\author{
Jeffrey L. Stith ${ }^{1}$, Brett Basarab ${ }^{2, a}$, Steven A. Rutledge ${ }^{2}$, and Andrew Weinheimer ${ }^{1}$ \\ ${ }^{1}$ National Center for Atmospheric Research, Box 3000, Boulder, Colorado 80307, USA \\ ${ }^{2}$ Colorado State University, 3915 W Laport Ave, Fort Collins, Colorado 80523, USA \\ ${ }^{a}$ now at: Global Weather Corporation, Boulder, Colorado, USA \\ Correspondence to: Jeffrey L. Stith (stith@ucar.edu)
}

Received: 25 September 2015 - Published in Atmos. Chem. Phys. Discuss.: 12 November 2015

Revised: 26 January 2016 - Accepted: 10 February 2016 - Published: 26 February 2016

\begin{abstract}
Thunderstorm anvils were studied during the Deep Convective Clouds and Chemistry experiment (DC3), using in situ measurements and observations of ice particles and $\mathrm{NO}_{x}$ together with radar and Lightning Mapping Array measurements. A characteristic ice particle and $\mathrm{NO}_{x}$ signature was found in the anvils from three storms, each containing high lightning flash rates in the storm core prior to anvil sampling. This signature exhibits high concentrations of frozen droplets (as measured by a Cloud Droplet Probe) coincident with lower $\mathrm{NO}_{x}$ on the edges of the anvil. The central portion of these anvils exhibited a high degree of aggregation of these frozen droplets and higher levels of $\mathrm{NO}_{x}$. In contrast, a deep convective cell with low lightning flash rates had high concentrations of both frozen droplets and aggregated frozen droplets in its anvil's central region. A conceptual model for these results is presented and applied to the observations from each of these storms. High $\mathrm{NO}_{x}$ concentrations are often found where aggregation of frozen droplets has occurred, which may be a reflection of aggregation by electrical forces in the regions where lightning is occurring, although the level of $\mathrm{NO}_{x}$ for a given concentration of aggregates varies from storm to storm. These observations between anvil microphysics and lightning and/or $\mathrm{NO}_{x}$ signatures suggest that lightning data may be an important tool to characterize or infer the microphysical, radiative, and chemical properties of thunderstorm anvils.
\end{abstract}

\section{Introduction}

Although lightning is considered to be a major source of $\mathrm{Ni}$ trogen Oxides $\left(\mathrm{NO}_{x}=\mathrm{NO}+\mathrm{NO}_{2}\right)$ to the upper troposphere (e.g., Ridley et al., 1996; Schumann and Huntrieser, 2007), our understanding of the relationships between thunderstorm cloud characteristics and resulting $\mathrm{NO}_{x}$ is not well understood. Programs such as the Stratospheric-Tropospheric Experiment: Radiation, Aerosols, and Ozone (STERAO, Dye et al., 2000) and others have demonstrated that much of the lightning-produced $\mathrm{NO}_{x}$ is transported by the parent storm to the upper-anvil cirrus cloud, where it has a long residence time in the upper troposphere.

The microphysical environment responsible for the storm electrification that ultimately produces lightning is thought to be one where collisions between ice particles occur in a riming environment, that is, supercooled liquid water is present (e.g., Takahashi, 1978; Baker and Dash, 1994). The updraft region of strong convective storms provides an ideal environment for this electrification and also redistributes the resulting charged particles in the storm due to convective updrafts and gravitational settling, resulting in the formation of bulk charge centers between which electrical breakdown occurs (Williams et al., 1991). When lightning occurs in such an updraft region, $\mathrm{NO}_{x}$ and hydrometeors with low fall velocity are transported by storm updrafts to the upper storm regions, where they can drift downstream from the parent storm, creating the classic thunderstorm anvil cloud. Of course, lighting can propagate outside of the updraft region, such as in cloud-to-ground lightning, so the formation of $\mathrm{NO}_{x}$ is not strictly limited to the updraft region. It can also occur in the 
anvil itself, which may also contribute to $\mathrm{NO}_{x}$ in the anvil (e.g., Dye and Willett, 2007; MacGorman and Rust, 1998). Our focus here is on storms that exhibited a high degree of electrical activity in the area of the main updraft, which was a common feature of many storms examined in this study, but does not include storms with a strong weak echo region.

Although the above scenario is a somewhat simplified description (e.g., it ignores the mesoscale dynamics of the anvil), it suggests that anvil regions containing high levels of $\mathrm{NO}_{x}$ could have a different microphysical history than adjacent regions with low $\mathrm{NO}_{x}$. However, few studies have linked the electrical activity or chemical properties of thunderclouds to the types of ice particles found within anvil clouds downstream of convective updrafts. The purpose of this study is to examine and explain some anvil microphysical signatures associated with high and low $\mathrm{NO}_{x}$ regions in anvils downwind of strongly electrified (i.e., high flash rates) cells over the continental United States (US). These storms were sampled during the Deep Convective Clouds and Chemistry Experiment (DC3; Barth et al., 2015, UCAR/NCAR, 2013).

\section{Previous work and experimental techniques}

\subsection{In situ data}

Stith et al. (2014) studied airborne microphysical data from the upper regions of several DC3 anvil clouds, in order to examine the occurrence and morphology of frozen-drop aggregates (FDAs) in the anvils of lightning-producing storms. FDAs are often found as long chain-like assemblages of individual frozen droplets, suggesting that the chains were formed by the action of electrical forces acting on the frozen droplets (e.g., see the review in Connolly et al., 2005). Some of the FDAs might also represent fragments of low-density graupel carried to the upper anvil by the storm updraft. As discussed in Stith et al. (2014) and Connolly et al. (2005), tropical anvils also contain chain-aggregate particles, but usually these chains are formed from chains of faceted ice crystals, rather than FDAs. Because the enhanced aggregation occurs via electrical forces, there is no requirement for lightning to occur, but Connolly et al. (2005) describes a threshold value of approximately $0.5 \times 10^{5} \mathrm{~V} \mathrm{~m}^{-1}$, which, depending on what is required for lightning initiation at the location of the aggregation, suggests that the two ought to often occur together or at least in close proximity.

In the Stith et al. (2014) study, the microphysical structure of two anvils that occurred in eastern Colorado on 6 June 2012 was examined using in situ hydrometeor imagery data and multiple Doppler radar analysis. They showed that the edges (and top of one) of the anvils contained primarily individual frozen droplets, while the central and lower parts of the upper anvil favored the presence of FDAs. That is, these upper anvil regions were primarily composed of frozen droplets with differing degrees of aggregation, with the aggregation of the frozen droplets most pronounced in the center and lower regions of the upper anvil. That study also examined other anvil regions from the DC3 program and found FDAs in many of the anvils, sometimes mixed with other ice particle types.

The primary aircraft used in this study is the NSF/NCAR G-V aircraft (UCAR/NCAR, 2015; also known as HIAPER). Since most of the instrumentation and sampling techniques were described in Stith et al. (2014), only a brief summary is presented here. Primary in situ cloud microphysical instruments include a modified Particle Measuring System (PMS) optical array probe (OAP-2DC, using high-speed electronics and a 64-element $25 \mu \mathrm{m}$ resolution diode array, which provides images of large particles and, as used here, concentrations of particles that image at least three diodes, or $75 \mu \mathrm{m}$ ), a Cloud Droplet Probe (CDP, manufactured by Droplet Measurement Technologies, DMT) for sampling cloud droplets in the $2-50 \mu \mathrm{m}$ diameter range (a recent calibration of the $\mathrm{CDP}$, using beam mapping, is used here, which produces $15 \%$ lower CDP concentrations than those reported in Stith et al., 2014), and a Stratton Park Engineering Company Inc. (SPEC) 3V-CPI, which contains a Cloud Particle Imager (CPI) with a resolution of $2.3 \mu \mathrm{m}$, which allows for highresolution imagery of particle morphology.

$\mathrm{NO}_{x}$ measurements were obtained from a 2-channel chemiluminescence instrument which detects NO via reaction with $\mathrm{O}_{3}$ to form excited $\mathrm{NO}_{2}$, which is detected via photon counting. One sample channel is used to measure nitric oxide, $\mathrm{NO}$, and the second measures nitrogen dioxide, $\mathrm{NO}_{2}$, by flowing ambient air through a glass cell illuminated by light-emitting diodes at $395 \mathrm{~nm}$, for the conversion of $\mathrm{NO}_{2}$ to NO via photolysis. The instrument is similar to instruments previously built at NCAR (Ridley and Grahek, 1990; Ridley et al., 2004), with an uncertainty of approximately $15 \%$.

In the upper anvil (typically colder than $-38^{\circ} \mathrm{C}$ ) several techniques were used by Stith et al. (2014) to identify regions of individual (non-aggregated) frozen droplets. These include the presence of relatively high (greater than $\sim 2 \mathrm{~cm}^{-3}$ ) CDP concentrations, the preponderance of small spherical images as the primary images on the CPI, and comparison of the water content from the CDP with simultaneous measurements of total water content from the University of Colorado closed-path laser hygrometer, version 2 (CLH2 , Dorsi et al., 2014). In regions where most of the frozen droplets had aggregated, the CDP concentrations dropped to $\sim 1 \mathrm{~cm}^{-3}$ or less, while the concentrations of particles on the 2DC increased, since the FDAs became large enough to be sampled by that instrument. Other details, including corrections for probe-tip shattering effects, are described in Stith et al. (2014).

\subsection{Lightning data}

For all cases, total lightning flash rates were determined from lightning mapping array (LMA) data in an effort to quantify 
the electrical vigor of the storms. LMAs offer a means to detect and spatially map lightning flashes occurring within thunderstorms, including both intracloud (IC) and cloud-toground (CG) flashes (Rison et al., 1999). An LMA detects radio frequency emissions at $\mathrm{VHF}(\sim 60-66 \mathrm{MHz})$ emitted during the electrical breakdown process preceding the visible lightning flash. Thus, regions of a storm with high VHF source activity indicate regions of frequent electrical breakdown. By appropriately clustering VHF sources associated with a single flash and attributing detected flashes to individual storms, an estimated flash rate can be determined. In this study, LMA-detected VHF sources were sorted into flashes using an automated density-based clustering algorithm developed by E. Bruning and B. Fuchs (Bruning, 2013) and discussed in more detail by Basarab et al. (2015) and Fuchs et al. (2015). The algorithm was shown by both studies to produce flash rates in close agreement to a previouslydeveloped LMA flash counting algorithm. For the 6 June and 15 June 2012 Colorado cases discussed herein, flash rates were derived from Colorado LMA data (Rison et al., 2012), while for the 25-26 May 2012 case, data from the central Oklahoma LMA were used (MacGorman et al., 2008).

In order to illustrate the locations of frequent electrical breakdown in storms (i.e., frequent lightning) for comparison with the radar data, the density of LMA sources were binned into the 0.5 by $0.5 \mathrm{~km}$ resolution (horizontal by vertical) radar grid, integrated along a specified spatial dimension to obtain a $2-\mathrm{D}$ projection, and then contoured in terms of the number per $0.25 \mathrm{~km}^{2}$ per radar scan time interval, which was approximately $4.5 \mathrm{~min}$. Flash rates are displayed only for the cell of interest, which was tracked by an automated cell tracking algorithm, developed by Lang and Rutledge (2011) and Fuchs et al. (2015). Because the sensitivities of the Colorado and Oklahoma networks are different, these contours should be interpreted only as a qualitative indicator of the regions of most intense electrical activity.

\subsection{Radar data}

This study relies on relating radar-inferred thunderstorm characteristics to in situ microphysical characteristics and lightning behavior. During DC3, coincident radar and LMA observations allowed for this comparison (Barth et al., 2015). As discussed in Stith et al. (2014), for the 6 June 2012 Colorado case, data from the CSU-CHILL S-band dualpolarization Doppler radar in Greeley, $\mathrm{CO}$ were employed (Junyent et al., 2013). The dual-polarization capabilities of the CHILL radar facilitated the identification of the dominant hydrometeor types in the 6 June case using a fuzzy-logic hydrometeor identification developed by Dolan et al. (2013). The 15 June 2012 case was out of range of the CHILL radar, so data from the National Weather Service (NWS) Weather Surveillance Radar 1998 Doppler (WSR-88D or NEXRAD) radar located near Denver, CO (KFTG) were used. Radar data for the 25-26 May 2012 case were obtained from the

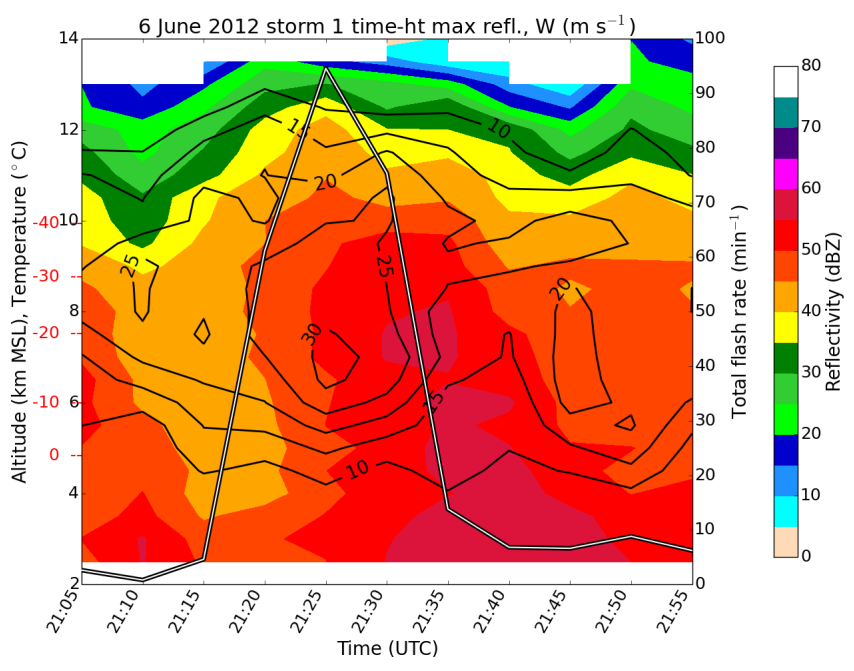

Figure 1. Time-height plot of maximum radar reflectivity (dBZ; colored contours with color scale at right) derived from CSUCHILL radar observations and dual-Doppler-derived maximum updraft ( $\mathrm{m} \mathrm{s}^{-1}$; black contours) for the 6 June 2012 southern cell. A time series of total lightning flash rate for this storm is superimposed (white line outlined in black). Altitude and temperatures (red text) derived from a proximity sounding are on the left-hand vertical axis; the flash rate scale is on the right-hand vertical axis.

Frederick, OK NEXRAD (KFDR). Although the KFTG and KFDR radars were equipped with single-polarization capabilities only during DC3, gridded reflectivity data for all cases facilitated the diagnosis of storm intensity and salient storm structural characteristics such as echo top height and the presence of a weak echo region.

Below, we examine the microphysical structure of the three aforementioned DC3 anvil case studies where lightning- $\mathrm{NO}_{x}$ was found, starting with the 6 June $2012 \mathrm{NO}_{x}$ plume that occurred with the frozen cloud droplets and FDAs described in Stith et al. (2014). We describe a simple conceptual model to explain the observations for storms such as the 6 June storm and then examine other anvils from DC3, some of which exhibited a more complex structure. Because airborne in situ measurements in the main updraft cores of the DC3 storms were restricted due to safety concerns, we use a combination of remote sensing and inference based upon what microphysical features were observed in the anvil to explain the likely chain of events linking $\mathrm{NO}_{x}$ observations to ice particle types in the anvil.

\section{$3 \mathrm{NO}_{x}$ plume structure in isolated anvils from strongly electrified cells}

\subsection{The 6 June storms}

Early airborne sampling began at 21:35 (all times are UTC) on the two storms on 6 June. At this point, they were isolated single-cell storms with radar echo tops exceeding $15 \mathrm{~km}$ 

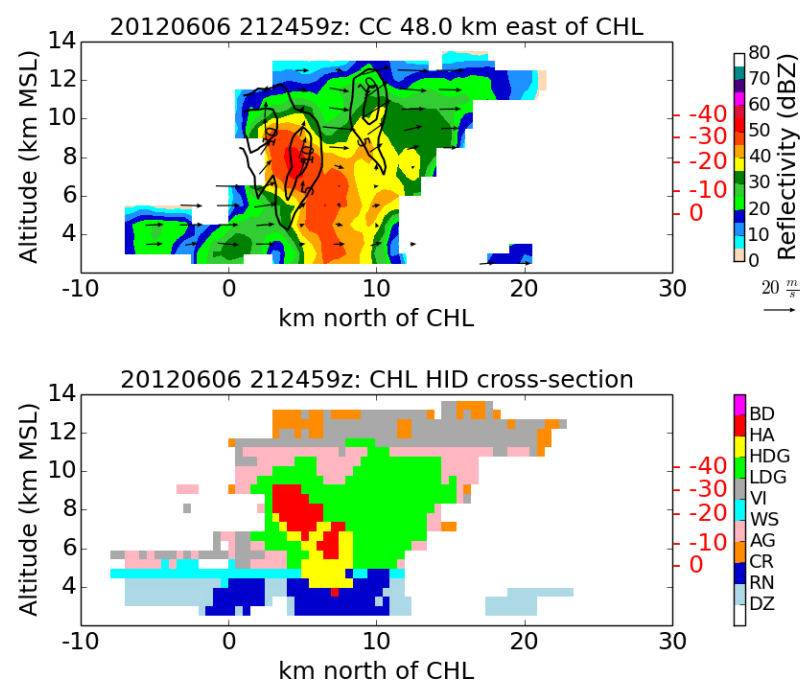

Figure 2. Two-panel plot of a south-north cross-section through the main updraft core of the 6 June southern storm at 21:25. (a) CSUCHILL radar reflectivity (dBZ; colored contours), winds (arrows, scale at right), and updraft ( $\mathrm{ms}^{-1}$; black contours) in the crosssection. (b) results of the polarimetric radar-based hydrometeor identification (HID) using CSU-CHILL polarimetric variables. The regions are identified as BD (big drops/melting hail), HA (Hail), HDG (high-density graupel), LDG (low-density graupel), VI (vertical ice), WS (wet snow), AG (aggregates), CR (ice crystals), RN (rain), and DR (drizzle). Temperatures $\left({ }^{\circ} \mathrm{C}\right)$ derived from a proximity sounding are indicated by the red text on the right-hand vertical axis.

(mean sea level, m.s.l.) altitude (Fig. 1, Stith et al., 2014). Later sampling between 22:12 and 22:30 was conducted in the upper, downstream anvil. Assuming that the ice particles sampled in the anvil originated in the main cell and drifted with the ambient wind, they would have originated in the main cell at approximately 21:25. Dual Doppler analysis of the wind and reflectivity field for the southern storm at 21:25 (Stith et al., 2014, Fig. 13), indicated that the storm was without a major downdraft region, with only the beginnings of the anvil indicated, and without a significant weak echo region. A radar time height cross section of the storm, together with the storm total flash rate is provided in Fig. 1 and a Doppler radar analysis is provided in Fig. 2. The maximum radar-derived updraft speeds were about $30 \mathrm{~m} \mathrm{~s}^{-1}$, and updraft speeds greater than $15 \mathrm{~m} \mathrm{~s}^{-1}$, extending between 6 and $12 \mathrm{~km}$ (Figs. 1 and 2). At the higher altitudes, these strong updrafts extended higher (colder) than the homogeneous freezing threshold. Flash rates, determined from the Colorado LMA network, exceeded 90 flashes per minute (Fig. 1), with most of the flashes in the upper portion of the storm (Fig. 3), indicating electrification in the main updraft regions. High radar reflectivity, consistent with large graupel particles (which were also identified by radar-based hydrometeor identification, Fig. 2, bottom) was present in the main cell. FDAs and frozen droplets sampled between 22:12
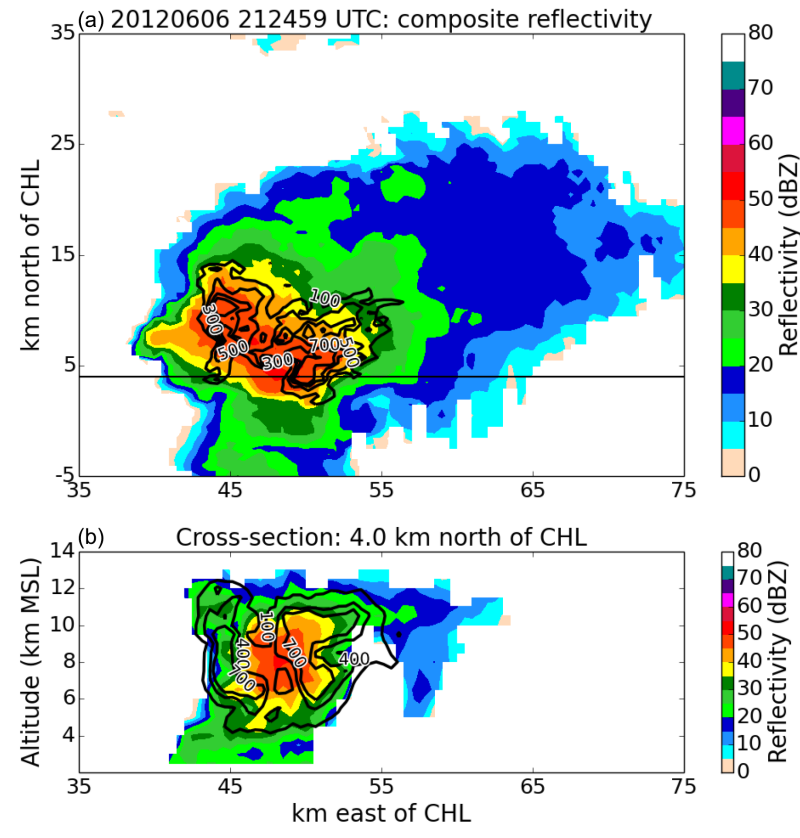

Figure 3. Two-panel plot of (a) composite radar reflectivity in plan view and (b) west-east cross-section through the 6 June 2012 case at 21:25. The radar reflectivity shown was retrieved by the CSUCHILL radar. The position of the cross-section shown in (b) is indicated by the thin black horizontal line in (a). The black contours superimposed on the radar reflectivity are (a) contours of vertically integrated LMA VHF source densities (b) LMA source densities horizontally integrated in the north-south direction. Contours indicate regions of frequent lightning discharges (large numbers of LMA-detected sources).

and 22:30 were likely formed during the period of maximum flash rate and then drifted downwind where they were sampled by the G-V (see Stith et al., 2014, for examples of FDAs and frozen drop imagery).

A depiction of the G-V pass through the anvil is given in Fig. 4, along with corresponding measurements of CDP, $2 \mathrm{DC}$, and $\mathrm{NO}_{x}$ concentrations. Here, the CDP and 2DC represent individual frozen drop concentrations and FDA concentrations, respectively, as discussed in Stith et al. (2014) for this time period. Figure 4 indicates that the primary $\mathrm{NO}_{x}$ plume was co-located with the FDAs, but nearly absent on the edges of the cloud where individual frozen droplets dominated. Therefore, for this case, the upper anvil consisted of a central core of FDAs and high $\mathrm{NO}_{x}$, surrounded by cloud containing mostly individual frozen droplets, without appreciable $\mathrm{NO}_{x}$ enhancement.

\subsection{Observations from 15 June}

On 15 June 2012 the G-V made a series of passes through the anvil of a strong thunderstorm, as depicted in Figs. 5-6. Although Dual-Doppler analysis for this case was not possible, the core of the storm generated a reflectivity of over $50 \mathrm{dBZ}$, 

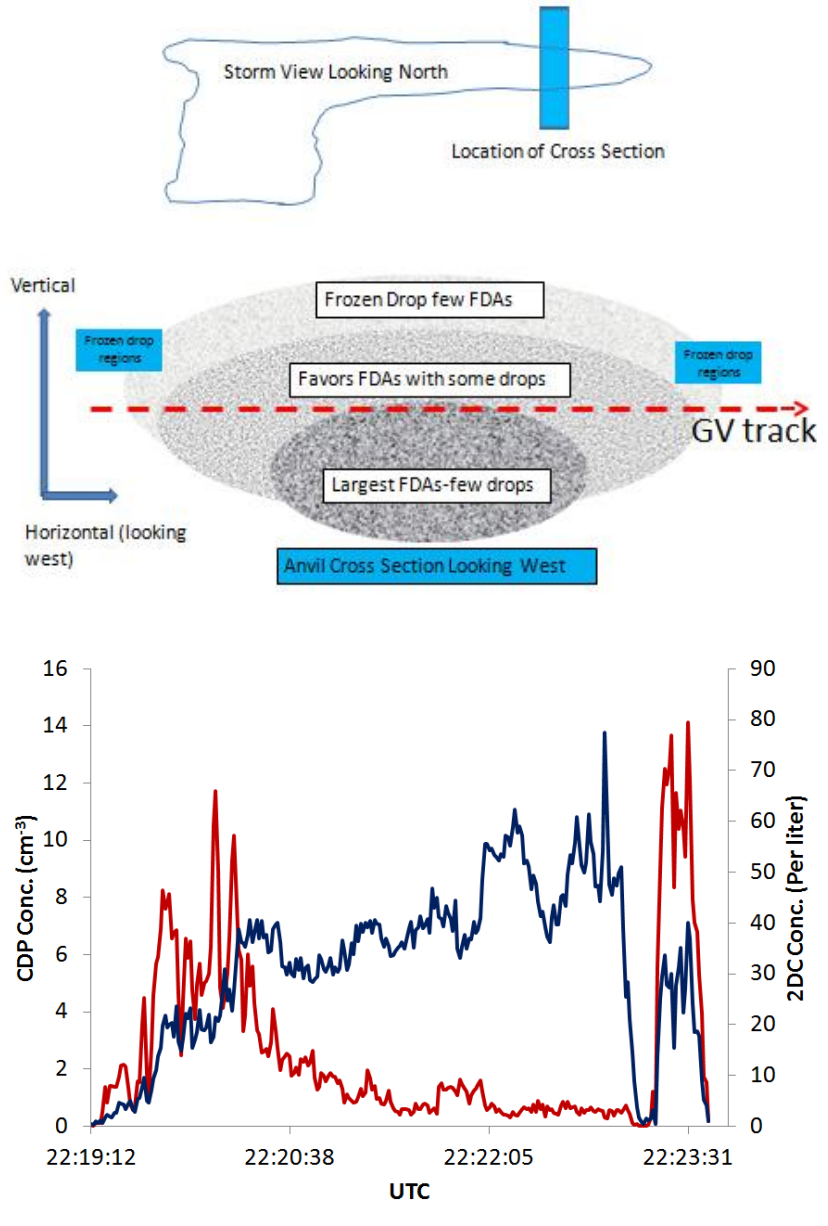

$-\mathrm{CDP}-2 \mathrm{DC}$

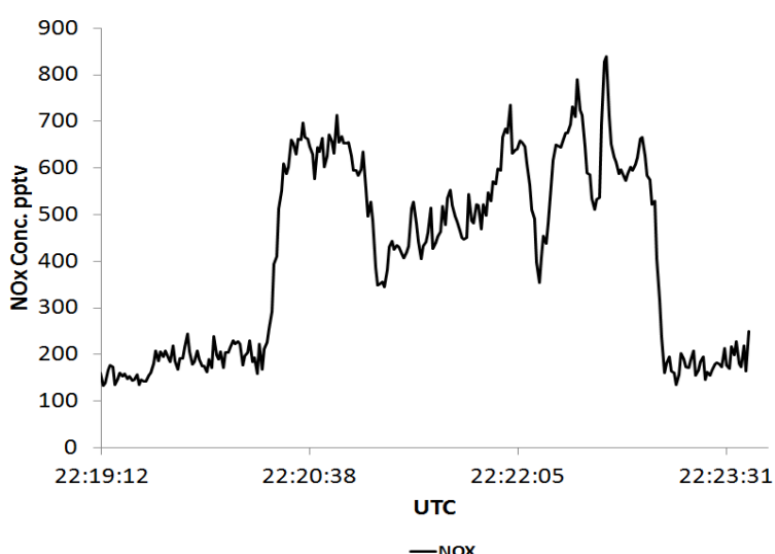

Figure 4. Schematic of the storm anvil in cross section on 6 June 2012 showing cross section of frozen drops and FDAs together with track of the G-V (top), CDP concentrations, and 2DC concentration during pass across the anvil at a temperature of approximately $-57^{\circ} \mathrm{C}$ (middle), $\mathrm{NO}_{x}$ concentrations during the pass (bottom). (Top and middle figures adapted from Stith et al., 2014).
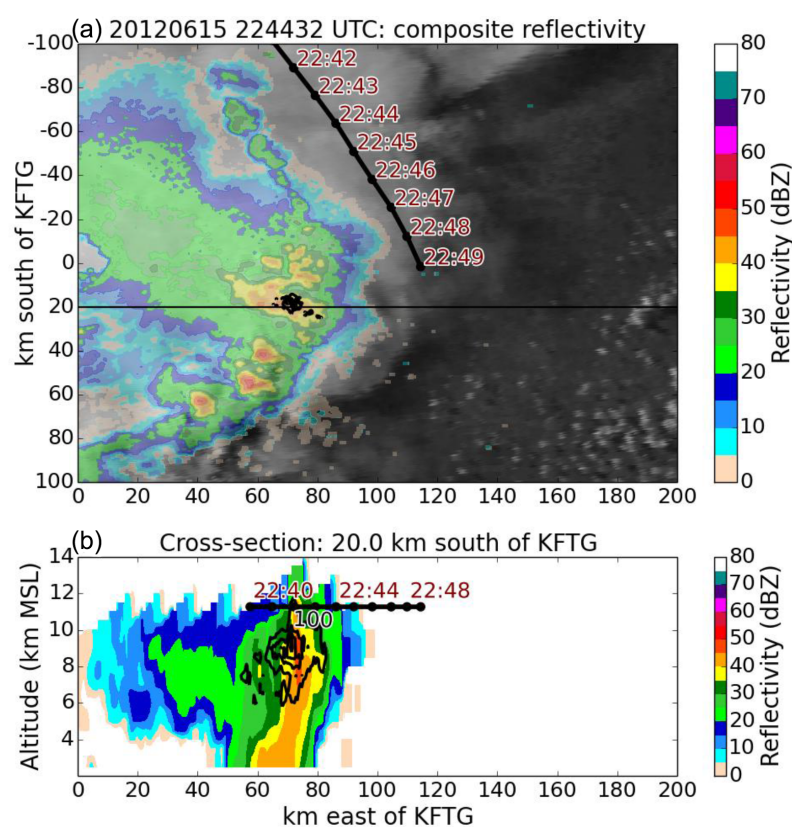

Figure 5. Two-panel plot of (a) composite reflectivity (dBZ; colored contours) in plan view superimposed on GOES-West visible satellite imagery and (b) west-east radar reflectivity cross-section through the 15 June 2012 case at 22:44. Radar reflectivity is from the KFTG (Denver, CO) NEXRAD radar. The G-V flight track from $22: 40$ to $22: 49$ is indicated by the thick black line; the G-V position at every minute is indicated by the black dots along the line, and UTC times along the track are labeled in brown. The position of the cross-section in (b) is indicated by the thin black horizontal line in (a). The black contours superimposed on the radar reflectivity are (a) contours of vertically integrated LMA VHF source densities (b) LMA source densities horizontally integrated in the north-south direction. Contours indicate regions of frequent lightning discharges (large numbers of LMA-detected sources).

echo tops above $13 \mathrm{~km}$ and flash rates of up to $50 \mathrm{~min}^{-1}$ (Figs. 5 and 6) prior to anvil sampling. The largest flash rates occurred between 6 to $10 \mathrm{~km}$ altitude, near and adjacent to the highest reflectivity maximum (Fig. 5) and just below the altitude that was sampled by the G-V.

The highest $\mathrm{NO}_{x}$ concentrations encountered by the $\mathrm{G}-\mathrm{V}$ occurred at approximately $22: 47$. $\mathrm{NO}_{x}$ and ice particle concentrations during this pass through the anvil are presented in Fig. 7. Even though the flash rate was somewhat lower in comparison to the 6 June 2012 case, $\mathrm{NO}_{x}$ concentrations in this pass were higher. The highest flash density was observed in the area of the main cell between 6 to $10 \mathrm{~km}$ altitude (Fig. 5). As with the 6 June case, CDP concentrations were higher on the edges of the anvil, but decreased within the central $\mathrm{NO}_{x}$ plume. 2DC concentrations increased in the $\mathrm{NO}_{x}$ plume, but decreased in the regions where CDP concentrations were higher on the edges of the anvil. Overall, the pattern is very similar to the 6 June case, with low $\mathrm{NO}_{x}$ associated with high CDP concentrations and higher $\mathrm{NO}_{x}$ as- 


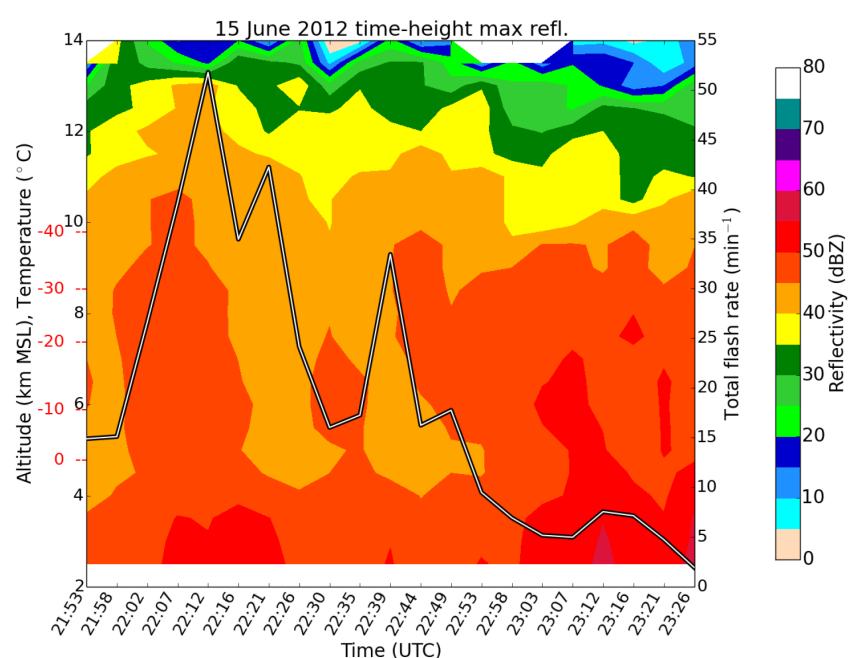

Figure 6. As in Fig. 1, but for the 15 June 2012 storm. Maximum updraft contours are not included because due to this storm's location, a dual-Doppler analysis could not be performed.

sociated with higher $2 \mathrm{DC}$ concentrations. The largest $\mathrm{NO}_{x}$ peak concentration coincided with a local minimum in the CDP concentration (Fig. 7).

As was true for the 6 June case (Stith et al., 2014), examination of the CPI data from the two regions confirms the presence of many frozen drop images in the high CDP region (Fig. 8 top) and FDA images in the high $\mathrm{NO}_{x}$ region (Fig. 8 bottom). The CDP concentrations adjacent to the peak $\mathrm{NO}_{x}$, in the central $\mathrm{NO}_{x}$ region, while low $\left(\sim 1 \mathrm{~cm}^{-3}\right)$, suggested that some individual frozen droplets remained alongside FDAs. This is confirmed by the images from the CPI. Aggregates, including many FDAs, were the primary type of large particle observed from this anvil pass, with occasional faceted crystals also found in the imagery.

\section{A conceptual model for the $\mathrm{NO}_{x}$ and microphysical structure of the isolated anvils}

Based upon the characteristics of the developing main cell of the 6 and 15 June storms, and the subsequent observations of frozen droplets and $\mathrm{NO}_{x}$ in the anvils, we suggest a conceptual model to explain these observations. The salient main cell characteristics include a deep $(6-12 \mathrm{~km})$ and vigorous updraft ( $>15 \mathrm{~m} \mathrm{~s}^{-1}$ for the 6 June case), coinciding with the region of most intense lightning activity, which occurred at the time when ice particles from the main cell would have been deposited to the upper troposphere to form the anvils that were sampled by the G-V.

Figure 9 presents a conceptual model of microphysical processes in the main cell of the 6 and 15 June cases to explain the observed structure of $\mathrm{NO}_{x}$ and ice particles in the anvil. The thesis is that the central core of the updraft is strong enough to contain supercooled water needed for

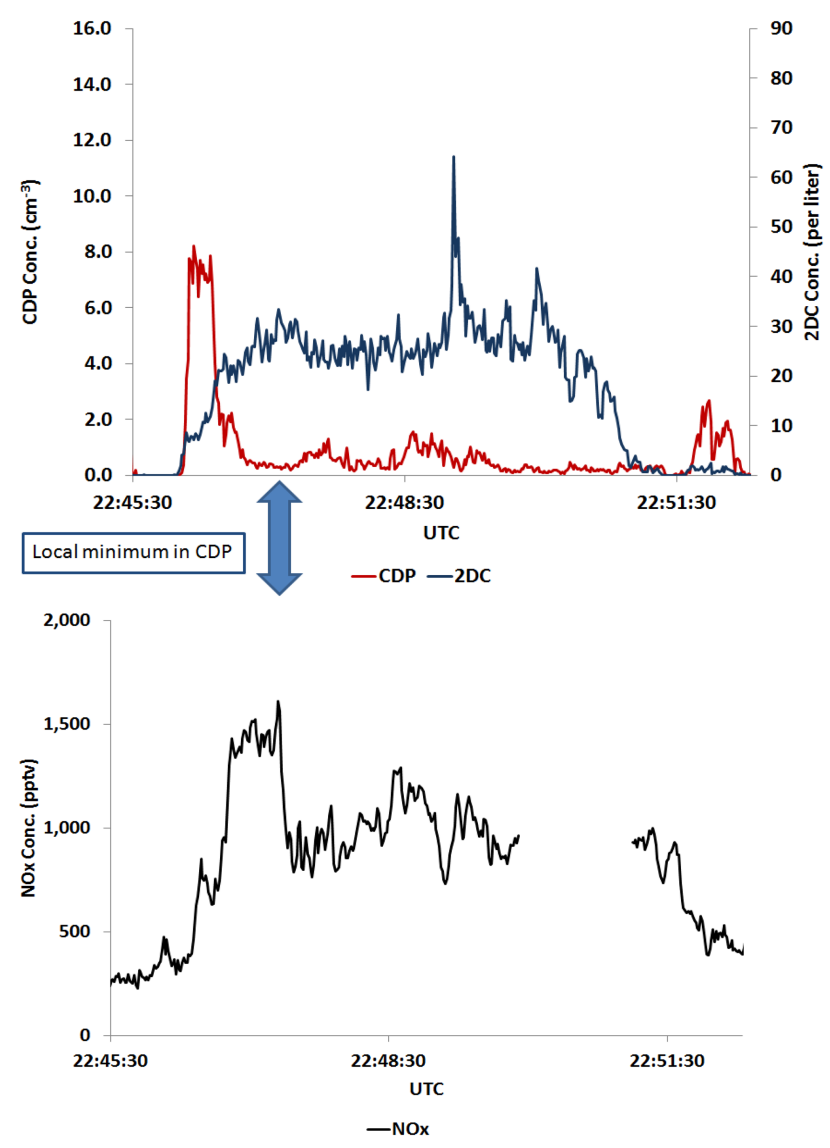

Figure 7. Concentrations from the CDP (red) and 2DC (blue) instruments (top), and corresponding $\mathrm{NO}_{x}$ concentrations (bottom) for a $\mathrm{G}-\mathrm{V}$ pass through the anvil on 15 June 2012 at altitudes of 11.7 to $12.2 \mathrm{~km}$ and temperatures of -56.6 to $-53.5^{\circ} \mathrm{C}$.

heavy riming (i.e., graupel or small hail production) and subsequent electrification and lightning in that region. While some of the largest graupel and/or hail hydrometeors are able to fall through the updraft, the $\mathrm{NO}_{x}$ and low fall velocity particles are carried up to near the top of the cloud before being detrained in the upper troposphere, creating the central core of the upper anvil as they drift downstream. In this region the low fall velocity particles often are composed of FDA's, which are hypothesized to result from one of two microphysical processes: either the electrical aggregation of frozen droplets in the high electric fields present in the main updraft, or, the FDAs might represent low density graupel or fragments of very low-density graupel, which are created during the riming process (see Stith et al., 2014, for more explanation). Due to the size and location of the updraft, the low fall velocity hydrometeors (predominantly FDAs) are carried through the homogeneous freezing altitude, where any remaining droplets are frozen, although the model would be similar if droplet freezing actually occurred at warmer temperatures. At the edges of the updraft core, the updraft is still strong and deep enough to provide frozen 

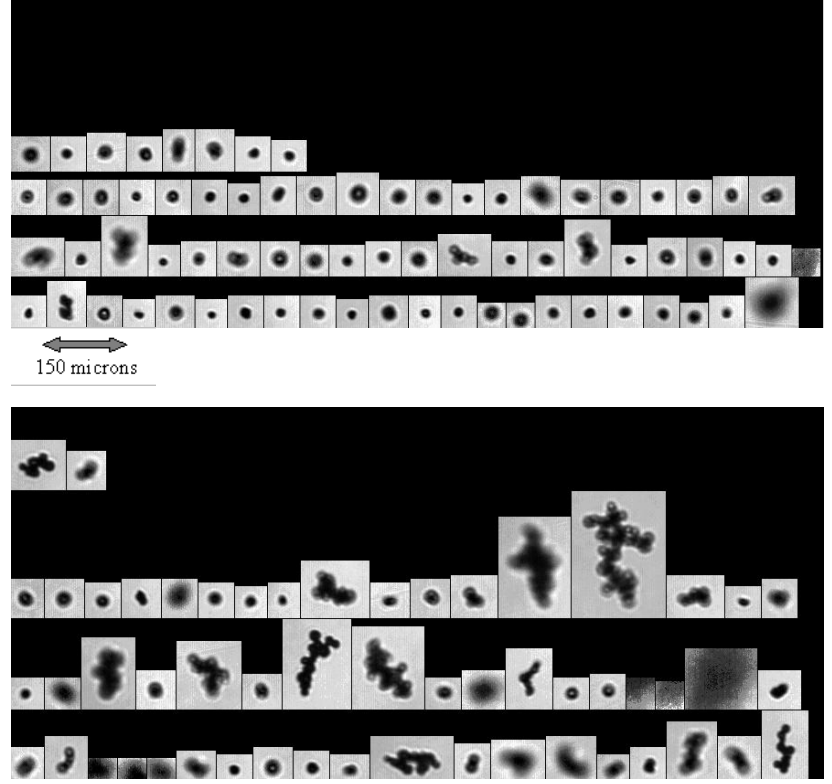

Figure 8. Examples of CPI images on the edges of the anvil (22:46:12 to $22: 46: 14$ top) and in the region of the peak in $\mathrm{NO}_{x}$ (22:47:04 to $22: 47: 06$, bottom), corresponding to the data presented in Fig. 7.

droplets to the upper anvil, but, due to the somewhat lower updraft velocity, the riming process (and consequently the electrification and lightning) is reduced, resulting in lower or no $\mathrm{NO}_{x}$ production on the edges of the updraft and favoring un-aggregated frozen droplets rather than FDAs. Thus, the detrainment to the upper anvil consists of a central region of FDAs and higher $\mathrm{NO}_{x}$, surrounded by low $\mathrm{NO}_{x}$ with mostly un-aggregated frozen droplets on the edges of the core (Fig. 9).

Of course, this model is designed to offer an explanation for storms where a large fraction of the flashes are located in the upper part of the updraft associated with the main cell, such as was the case for the 6 and 15 June cases. This may reflect the fact that these storms were sampled early in their life cycle. A different model would likely apply when the heaviest lightning activity was not located in the main updraft region, such as storms where the main electrical activity occurs in the anvil, for storms at a different stage of their life cycle, or for storms with significantly different updraft profiles.

\section{Comparison with a multiple-anvil storm on 25/26 May containing cells with differing lighting activity}

Anvil encounters during DC3 were often associated with multi-cellular features. The anvil encountered on 2526 May 2012 provides a good example for comparison with the above cases because the observations include anvil regions downstream of both an electrically active cell and a
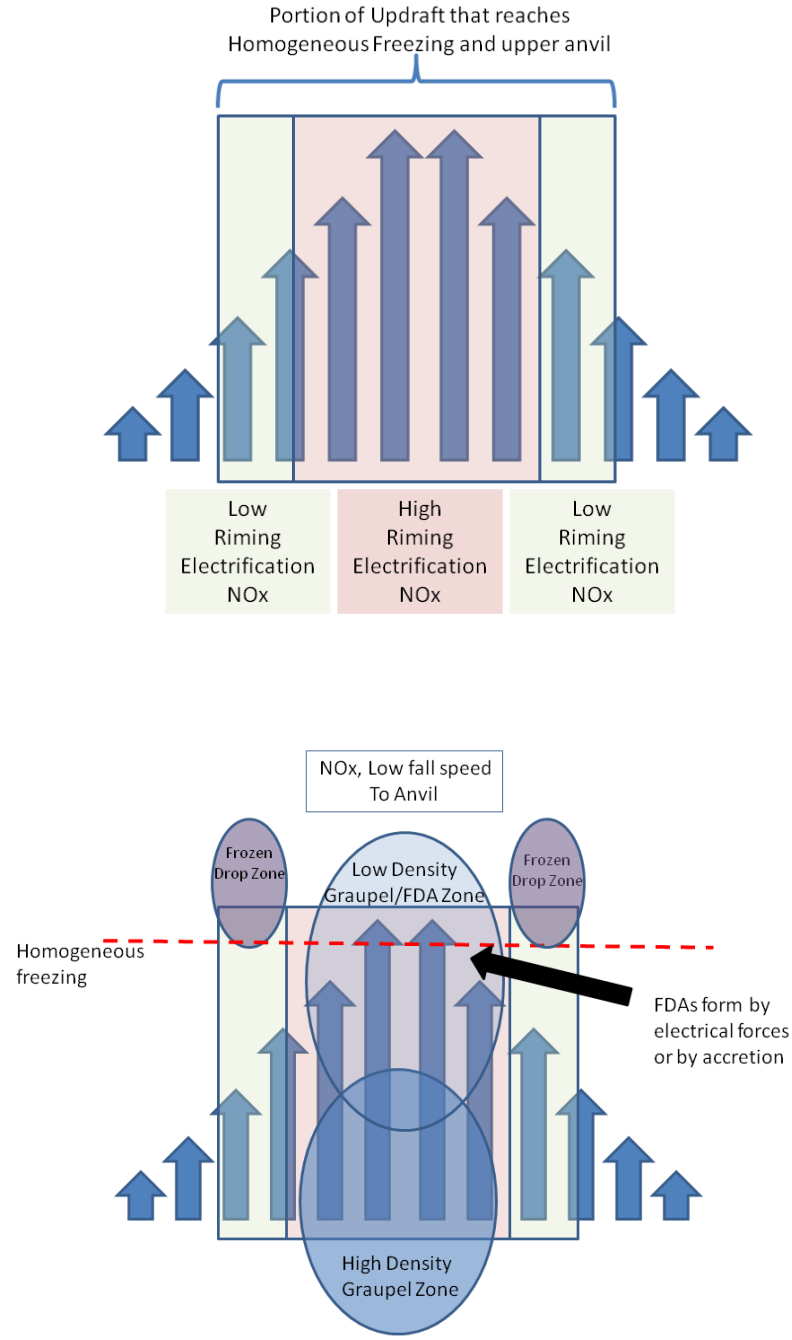

Figure 9. Conceptual model of the 6 and 15 June cases showing processes likely in the main cell (top) and the resulting microphysical structure (bottom). See text for more explanation.

much weaker cell. This allows for comparison of the anvil microphysics and $\mathrm{NO}_{x}$ resulting from a weakly electrified cell and a strongly electrified cell which were in close proximity.

The G-V began sampling an anvil at approximately 00:40 on 26 May 2012. During the first pass through the anvil the $\mathrm{NO}_{x}$ and ice concentrations suggested two separate segments (Fig. 10). Evidently, at this stage the anvils from two cells had recently merged, yet were still distinct enough to offer two separate segments. Radar data and flash locations from the cells upstream of the two segments are presented in Figs. 11 and 12 and LMA/radar time-height cross sections of the cells are presented in Figs. 13 and 14. As with the 6 and 15 June cases, the heaviest flash locations were in the upper part of the main cell regions (approximately 7 to $12 \mathrm{~km}$ for the northern cell and 5 to $12 \mathrm{~km}$ for the southern cell). 

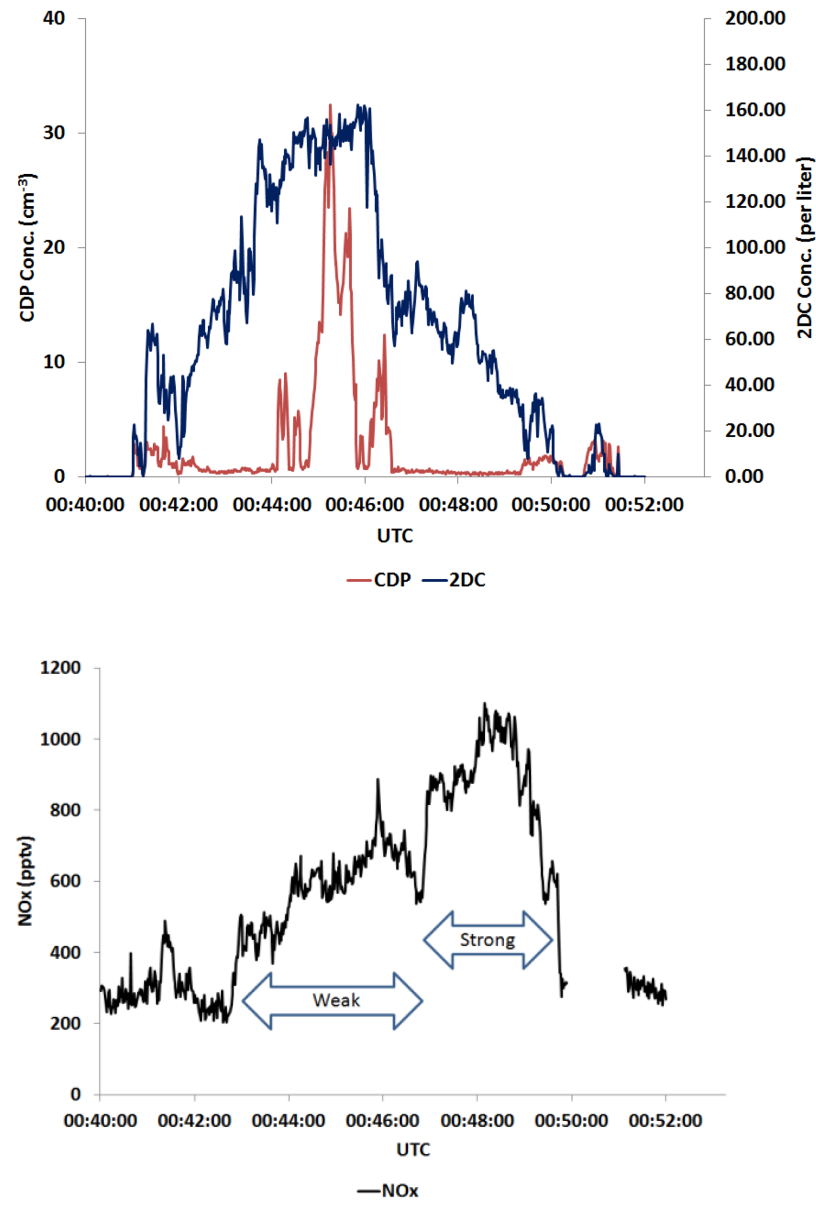

Figure 10. Concentrations from the CDP (red) and 2DC (blue) instruments (top), and corresponding $\mathrm{NO}_{x}$ concentrations (bottom) for a pass through the anvil of the 25/26 May 2012 case at an altitude of $12.1 \mathrm{~km}$ and temperatures of -50.8 to $-54.2^{\circ} \mathrm{C}$. Anvil regions downstream of the electrically weak and strong cells are indicated.

The first segment of the anvil pass was through an anvil downstream of an older, less electrically active cell on the northern part of the storm complex (Figs. 11 and 13; referred to as the weak cell) while the second part of the pass was through an anvil region downstream of a newer, more electrically active cell to the south (Figs. 12 and 14), referred to as the strong cell. The strong cell exhibited high flash rates and reflectivity signatures consistent with hail production (Fig. 14). The weak cell had echo tops above about $13 \mathrm{~km}$ and reflectivity above $50 \mathrm{dBZ}$, but had a very low lightning flash rate and lower reflectivity overall than the strong cell. Significantly higher $\mathrm{NO}_{x}$ was found in the second part of the pass ( $\sim 00: 46: 30$ to 00:49:00 in Fig. 10$)$, downstream of the strong cell, which is not surprising, given the high flash rate from that cell. In this region the main peak in $\mathrm{NO}_{x}$ was between two regions with higher CDP concentrations. The boundaries of this part of the anvil exhibited an increase in
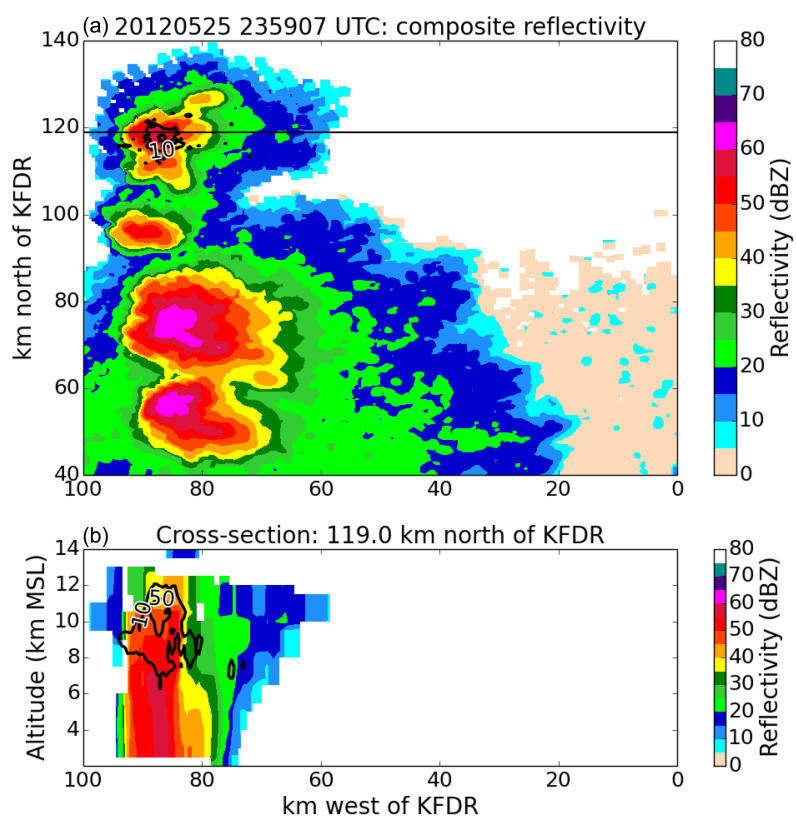

Figure 11. Two-panel plot of (a) composite radar reflectivity in plan view and (b) west-east cross-section through the 25-26 May 2012 case at 23:59:07, just prior to G-V sampling. The cross-section is taken through the weak northern cell. In this figure, the radar reflectivity is from the KFDR (Frederick, OK) NEXRAD radar. The position of the cross-section shown in (b) is indicated by the thin black horizontal line in (a). The black contours superimposed on the radar reflectivity are (a) contours of vertically integrated LMA VHF source densities (b) LMA source densities horizontally integrated in the north-south direction. Contours indicate regions of frequent lightning discharges (large numbers of LMA-detected sources).

CDP concentrations in a similar manner to the 6 and 15 June cases, with higher CDP concentrations at the edges of the anvil. In contrast, the northern segment of the anvil (the weak cell) exhibited both high CDP concentrations and high 2DC concentrations. CDP concentrations in the northern weak cell were the highest observed among the above anvil case studies. FDAs were a common type of large particle in both areas of the anvil with single frozen droplets also found with the aggregates, especially in regions with higher CDP concentrations. Stith et al. (2014) classified subsets of FDAs as internally mixed type 1 (frozen droplets aggregated with pristine crystals from warmer temperatures, typically plate crystals) and type 2 (frozen droplets with facets (typically columnar or bullet types) present that represent crystals grown near the sampling temperatures). Both of these types were present, as well as some aggregates of primarily faceted crystals.

The anvil downstream of the northern weak cell had peak ice water concentrations (as measured by the CLH-2 total water instrument) just over $\sim 0.5 \mathrm{~g} \mathrm{~m}^{-3}$, roughly a factor of 5 times higher than anvil downstream of the strong cell and also much higher than observed for the 6 and 15 June cases. Given the fact that the flash rate was much less than the other 

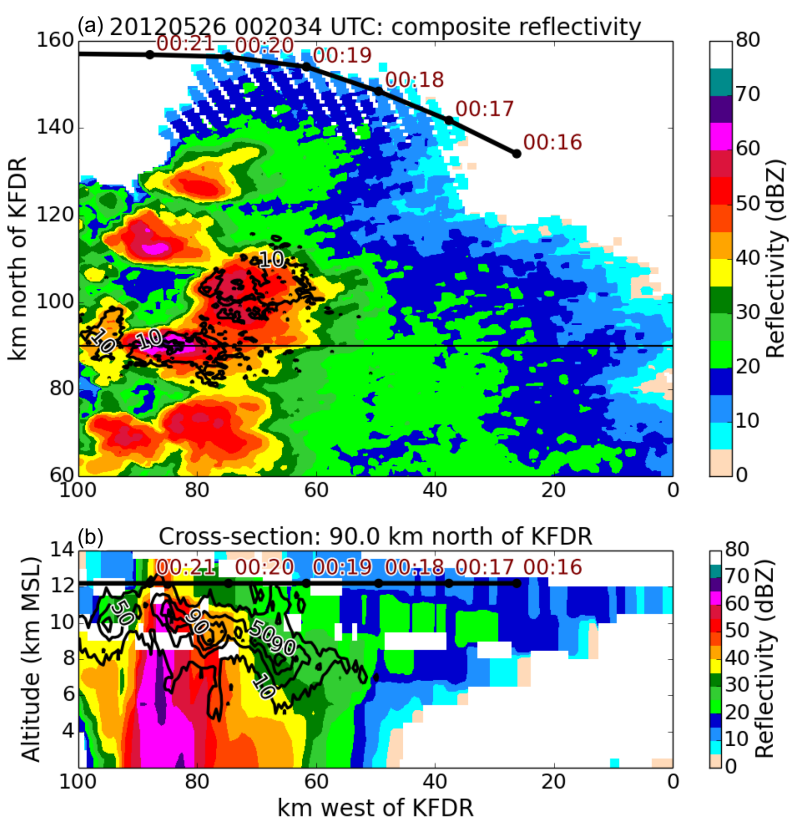

Figure 12. As in Fig. 10, except for the stronger southern cell at 00:20:34. Also, the G-V flight track in plan view and cross-section for several minutes near 00:20:34 is indicated by the thick black line. The G-V position at every minute is indicated by the black dots along the line, and UTC times along the track are labeled in brown.

storms that were studied, the level of $\mathrm{NO}_{x}$ found in this part of the anvil was also somewhat higher than expected. A likely explanation for this result is that the G-V was able to sample closer to the core of the weak cell than the strong cell, as seen in Fig. 12 where the G-V flight track passes through radardetected portions of the weak cell anvil. Closer sampling was possible due to the fact that the storm anvil was encountered during the weakening stages of this cell, when the lightning was essentially absent (e.g., Fig. 13) during the sampling.

Following the sampling of the storm a vertical profile was made just north-west of the storm in clear air from an altitude of 13 to $1.6 \mathrm{~km}$. $\mathrm{CO}, \mathrm{O}_{3}$, and $\mathrm{CO}_{2}$ concentrations (not shown) measured in the anvil were similar to those from $\sim 3$ to $6 \mathrm{~km}$ altitudes outside of the storm, suggesting that the source of the anvil air was from these lower altitudes, and that there was relatively little entrainment of air prior to anvil sampling. This suggests that differences in entrainment were not likely the source for the differences in frozen droplet or ice content.

\section{Discussion}

Data from three strongly electrified cells that have been studied to date exhibited a characteristic $\mathrm{NO}_{x}$ /ice signature in the upper anvil. This signature included a central region of high $\mathrm{NO}_{x}$ together with aggregated ice particles in the form of FDAs and other particle types. On the edges of the anvil, there appeared to be less aggregation and more individual

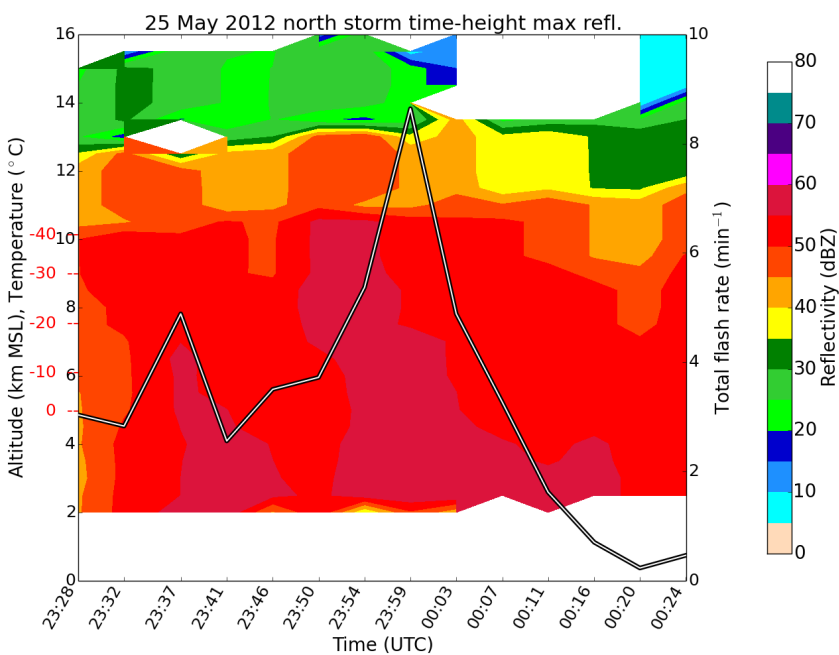

Figure 13. As in Fig. 6, but for the 25-26 May 2012 northern (weaker) cell.

frozen droplets, resulting in higher concentrations from the CDP instrument. Lower amounts of $\mathrm{NO}_{x}$ were found on the edges of the anvil clouds, coincident with the increased number of un-aggregated frozen droplets detected by the CDP. Some individual frozen droplets remained in the cores of these anvils, but regions with very strong $\mathrm{NO}_{x}$ peaks had corresponding minima in concentrations of frozen droplets as measured by the CDP (e.g., Figs. 7 and 10).

The pattern of frozen droplets and FDAs in the weak storm anvil on 25/26 May does not exhibit the same signature as the three other cases. It is noteworthy that this anvil contained high concentrations of both FDAs and un-aggregated frozen droplets in its central region, unlike the other cases, which favored FDAs over frozen droplets in their central regions. It also exhibited much higher total water content in its anvil, which suggests a low precipitation efficiency. To explain this signature in the pattern of FDAs and un-aggregated frozen droplets in the weak anvil pass, we refer to the conceptual model described in Fig. 9 and contrast the results from the strong storm with those from the weak storm. The strong storm exhibits a very high reflectivity in its lower regions (Figs. 12 and 14) indicating a pronounced zone of highdensity graupel and/or hail (depicted in the conceptual model at the lower portion of Fig. 9). In contrast, the weak storm exhibited lower reflectivity in its lower regions (Figs. 11 and 13), indicating a less pronounced zone of high-density graupel and/or hail when compared to the strong storm. Thus, it is likely that there was much more removal of droplets by high-density graupel and hail formation in the strong storm than in the weak storm. Consequently, many more droplets (as single frozen drops or FDAs) should have been available for upward transport in the central part of the weak storm, when compared with the strong storm, resulting in more of both types in the central region of the weak anvil. 


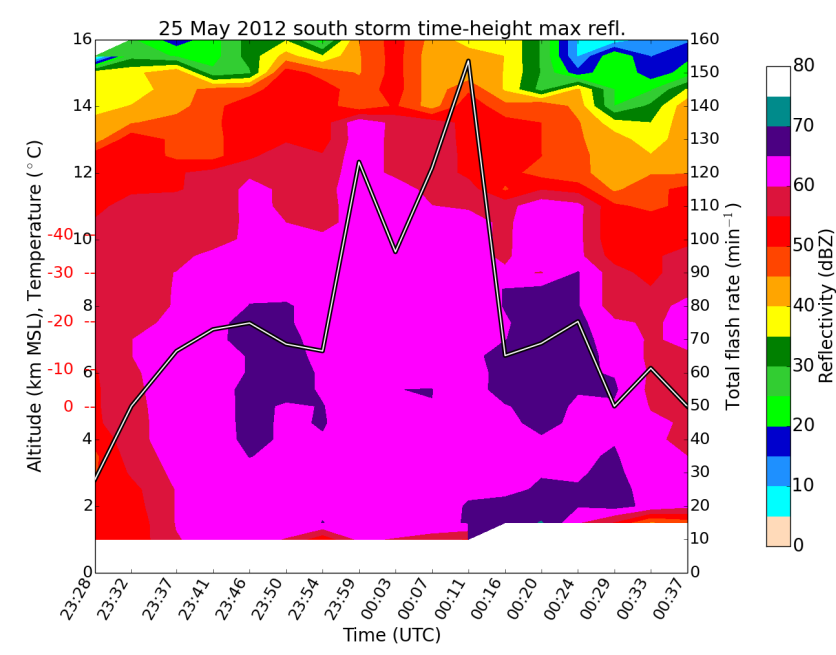

Figure 14. As in Fig. 6, but for the 25-26 May 2012 southern (stronger) cell.

The conceptual model described here is helpful in interpreting the observed signatures of $\mathrm{NO}_{x}$ and ice particles in the anvils that were sampled. These anvils were associated with developing cells with vigorous updrafts and a preponderance of lightning activity in the upper regions of the cells. A basic assumption is that high E-field regions exist in regions containing frozen droplets (where FDAs are formed) and these coincide with lightning channels where $\mathrm{NO}_{x}$ is formed, and this is why FDAs and $\mathrm{NO}_{x}$ are strongly correlated, first in the updraft (inferred) and then in the anvil (observed). Of course, this conceptual model and the associated $\mathrm{NO}_{x}$ /ice signatures should only apply to situations where this assumption is valid. The somewhat different signature pattern found in the anvil from the weak storm on 25/26 May appears to be consistent with the basic conceptual model, but illustrates that there is likely a wide variety of signatures that can occur under different storm conditions.

These results all support the reasonable expectation that ice particles found in the anvil are strongly related to the electrical properties of the storms and therefore they are also correlated in predictable ways with in situ $\mathrm{NO}_{x}$. For the cases studied, higher $\mathrm{NO}_{x}$ appears correlated with the occurrence of FDAs. Un-aggregated frozen droplets are often found in regions of lower $\mathrm{NO}_{x}$, such as on the edges of the storms, but in one case they were able to persist in the central region, probably because the droplets were not depleted at lower levels of the storm.

These results may have important applications. When relatively high levels of condensed water are present in the anvil as small frozen droplets, or larger low-density FDAs, they contribute relatively little to radar reflectivity, but may contain significant amounts of condensed water. High ice water content at low radar reflectivity near deep convection is of particular concern to the aviation industry (e.g., Fridlind et al., 2015, and references therein), due to the possibility that it contributes to jet engine power loss while being difficult to detect with airborne weather-avoidance radar. Our results suggest that the electrical properties of the convective storms may play a role in identifying the possible occurrence of high ice water and/or low reflectivity conditions.

While it is tempting to generalize the results from this study, it is important to note that the results from tropical maritime thunderstorms are likely to be much different, owing to the differences in updraft characteristics (e.g., Heymsfield et al., 2010; Anderson et al., 2005; Stith et al., 2006), which is likely the reason why they favor chains of faceted crystals over chains of frozen droplets in areas where aggregation by electrical forces is suspected (e.g., Connolly et al., 2005). In addition, tropical maritime thunderstorms likely have a weaker electric field, which would also influence the abundance of chain-aggregate type particles.

The conceptual model described here may explain some of the correspondence between $\mathrm{NO}_{x}$ levels and anvil microphysical structure but it is probably less applicable, for example, in the dissipating stages of the storms or for other storm conditions. For example, these signatures would be much less likely if most of the $\mathrm{NO}_{x}$ was generated below cloud (e.g., in CG flashes) or in the anvil itself. A significant scientific need is to understand the source regions for $\mathrm{NO}_{x}$ for a variety of storm types and conditions (e.g., storm age). Using the three sources of data (LMA, radar, in situ) a consistent description of the relationships between anvil $\mathrm{NO}_{x}$, lightning flash rates and hydrometeor types is possible. This can likely be done for a variety of storm conditions, thus developing a much better understanding of $\mathrm{NO}_{x}$ production overall. More work is needed to understand different types of storms, such as storms with weak echo regions or tropical storms.

Acknowledgements. The National Center for Atmospheric Research is sponsored by the National Science Foundation. Thanks are due to the many NCAR Earth Observing Laboratory staff that contributed to the collection of the data presented here and to helpful comments by James Dye. The Deep Convective Clouds \& Chemistry Experiment (DC3) was sponsored by the US National Science Foundation (NSF), the National Aeronautics and Space Administration (NASA), the National Oceanic and Atmospheric Administration (NOAA), and the Deutsches Zentrum fur Luft- und Raumfahrt (DLR). The Colorado State University authors were supported by the NSF grant, AGS-1429925 from the Physical and Dynamical Meteorology Program.

Edited by: H. Tost 


\section{References}

Anderson, N. F., Grainger, C. A., and Stith, J. L.: Characteristics of strong updrafts in precipitation systems over the central tropical Pacific Ocean and in the Amazon, J. Appl. Meteorol., 44, 731738, 2005

Baker, M. B. and Dash, J. G.: Mechanism of charge transfer between colliding ice particles in thunderstorms, J. Geophys. Res., 99, 10621-10626, doi:10.1029/93JD01633, 1994.

Barth, M. C., Cantrell, C. A., Brune, W. H., Rutledge, S. A., Crawford, J. H., Huntrieser, H., Carey, L. D., MacGorman, D., Weisman, M., Pickering, K. E., Bruning, E., Anderson, B., Apel, E., Biggerstaff, M., Campos, T., Campuzano-Jost, P., Cohen, R., Crounse, J., Day, D. A., Diskin, G., Flocke, F., Fried, A., Garland, C., Heikes, B., Honomichi, S., Hornbrook, R., Huey, L. G., Jimenez, J., Lang, T., Lichtenstern, M., Mikoviny, T., Nault, B., O’Sullivan, D., Pan, L., Peischl, J., Pollack, I., Richter, D., Riemer, D., Ryerson, T., Schlager, H., St. Clair, J., Walega, J., Weibring, P., Weinheimer, A., Wennberg, P., Wisthaler, A., Wooldridge, P., and Zeigler, C.: The Deep Convective clouds and Chemistry (DC3) Field Campaign, B. Am. Meteorol. Soc., 96, 1281-1309, doi:10.1175/BAMS-D-13-00290.1, 2015.

Basarab, B., Rutledge, S. A., and Fuchs, B. R.: An improved lightning flash rate parameterization developed from Colorado DC3 thunderstorm data for use in cloud-resolving chemical transport models, J. Geophys. Res., 120, 9481-9499, doi:10.1002/2015jd023470, 2015.

Bruning, E. C.: Streamed clustering of lightning mapping data in Python using sklearn, in: Scientific Computing With Python, 2, available at: https://www.youtube.com/watch? $\mathrm{v}=$ 0Z17Q22HEMI (last access: 21 February 2016), 2013.

Connolly, P. J., Saunders, C. P. R., Gallagher, M. W., Bower, K. N., Flynn, M. J., Choularton, T. W., Whiteway, J., and Lawson, R. P.: Aircraft observations of the influence of electric fields on the aggregation of ice crystals, Q. J. Roy. Meteor. Soc., 131, 16951712, doi:10.1256/qj.03.217, 2005.

Dolan, B., Rutledge, S. A., Lim, S., Chandrasekar, V., and Thurai, M.: A robust $\mathrm{C}$ - band hydrometeor identification algorithm and application to a long-term polarimetric radar dataset, J. Appl. Meteorol. Clim., 52, 2162-2186, 2013.

Dorsi, S. W., Kalnajs, L. E., Toohey, D. W., and Avallone, L. M.: A fiber-coupled laser hygrometer for airborne total water measurement, Atmos. Meas. Tech., 7, 215-223, doi:10.5194/amt-7-2152014, 2014.

Dye, J. E. and Willett, J. C.: Observed enhancement of reflectivity and the electric field in Long-lived florida anvils, Mon. Weather Rev., 135, 3362-3380, doi:10.1175/MWR3484.1, 2007.

Dye, J. E., Ridley, B. A., Skamarock, W., Barth, M., Venticinque, M., Defer, E., Blanchet, P., Thery, C., Laroche, P., Baumann, K., Hubler, G., Parrish, D. D., Ryerson, T., Trainer, M., Frost, G., Holloway, J. S., Matejka, T., Bartels, D., Fehsenfeld, F. C., Tuck, A., Rutledge, S. A., Lang, T., Stith, J., and Zerr, R.: An overview of the Stratospheric-Tropospheric Experiment: Radiation, Aerosols, and Ozone (STERAO)-Deep Convection experiment with results for the July 10, 1996 storm, J. Geophys. Res., 105, 10023-10045, doi:10.1029/1999JD901116, 2000.

Fridlind, A. M., Ackerman, A. S., Grandin, A., Dezitter, F., Weber, M., Strapp, J. W., Korolev, A. V., and Williams, C. R.: High ice water content at low radar reflectivity near deep convection - Part 1: Consistency of in situ and remote-sensing observations with stratiform rain column simulations, Atmos. Chem. Phys., 15, 11713-11728, doi:10.5194/acp-15-11713-2015, 2015.

Fuchs, B. R., Rutledge, S. A., Bruning, E. C., Pierce, J. R., Kodros, J. K., Lang, T. J., MacGorman, D., Krehbiel, P., and Rison, W.: Environmental controls on storm intensity and charge structure in multiple regions of the continental United States, J. Geophys. Res., 120, 6575-6596, doi:10.1002/2015JD023271, 2015.

Heymsfield, G. M., Tian, L., Heymsfield, A. J., Li, L., and Guimond, S.: Characteristics of Deep Tropical and Subtropical Convection from Nadir-Viewing High-Altitude Airborne Doppler Radar, J. Atmos. Sci., 67, 285-308, doi:10.1175/2009JAS3132.1, 2010.

Junyent, F., Chandrasekar, V., Kennedy, P., Rutledge, S., Bringi, V., George, J., and Brunkow, D.: Salient Features of the CSU-CHILL radar x-band channel upgrade, available at: https://ams.confex.com/ams/36Radar/webprogram/ Manuscript/Paper229162/2B6_AMS.pdf (last access: 21 February 2016), 2013.

Lang, T. J. and Rutledge, S. A.: A framework for the statistical analysis of large radar and lightning datasets: Results from STEPS 2000, Mon. Weather Rev., 139, 2536-2551, 2011.

MacGorman, D. R. and Rust, W. D.: The electrical nature of storms, Oxford University Press, 423 pp., 1998.

MacGorman, D. R., Rust, W. D., Schuur, T. J., Biggerstaff, M. I., Straka, J. M., Ziegler, C. L., Mansell, E. R., Bruning, E. C., Kuhlman, K. M., Lund, N. R., Biermann, N. S., Payne, C., Carey, L. D., Krehbiel, P. R., Rison, W., Eack, K. B., and Beasley, W. H.: TELEX: The Thunderstorm Electricity and Lightning Experiment, B. Am. Meteorol. Soc., 89, 997-1013, 2008.

Ridley, B. A. and Grahek, F. E.: A small, low flow, high-sensitivity reaction vessel for NO chemiluminescence detectors, J. Atmos. Ocean. Tech., 7, 307-311, 1990.

Ridley, B. A., Dye, J. E., Walega, J. G., Zheng, J., Grahek, F. E., and Rison, W.: On the production of active nitrogen by thunderstorms over New Mexico, J. Geophys. Res., 101, 20985-21005, doi:10.1029/96JD01706, 1996.

Ridley, B. A., Ott, L., Pickering, K., Emmons, L., Montzka, D., Weinheimer, A., Knapp,D., Grahek, F., Li, L., Heymsfield, G., McGill, M., Kucera, P., Mahoney, M. J., Baumgardner, D., Schultz, M., and Brasseur, G.: Florida thunderstorms: A faucet of reactive nitrogen to the upper troposphere, J. Geophys. Res., 109, D17305, doi:10.1029/2004JD004769, 2004.

Rison, W., Thomas, R. J., Krehbiel, P. R., Hamlin, T., and Harlin, J.: A GPS- based three-dimensional lightning mapping system: Initial observations in central New Mexico, Geophys. Res. Lett., 26, 3573-3576, 1999.

Rison, W., Krehbiel, P. R., Thomas, R. J., Rodeheffer, D., and Fuchs, B.: The Colorado lightning mapping array, American Geophysical Union fall meeting, December 2012 (poster), 2012.

Schumann, U. and Huntrieser, H.: The global lightning-induced nitrogen oxides source, Atmos. Chem. Phys., 7, 3823-3907, doi:10.5194/acp-7-3823-2007, 2007.

Stith, J. L., Haggerty, J., Grainger, C., and Detwiler, A.: A comparison of the microphysical and kinematic characteristics of midlatitude and tropical convective updrafts and downdrafts, Atmos. Res., 82, 350-366, 2006.

Stith, J. L., Avallone, L. M., Bansemer, A., Basarab, B., Dorsi, S. W., Fuchs, B., Lawson, R. P., Rogers, D. C., Rutledge, S., and Toohey, D. W.: Ice particles in the upper anvil regions of midlat- 
itude continental thunderstorms: the case for frozen-drop aggregates, Atmos. Chem. Phys., 14, 1973-1985, doi:10.5194/acp-141973-2014, 2014.

Takahashi, T.: Riming electrification as a charge generation mechanism in thunderstorms, J. Atmos. Sci., 35, 1536-1548, 1978.

UCAR/NCAR: Earth Observing Laboratory. Low Rate (LRT - 1 sps) Navigation, State Parameter, and Microphysics Flight-Level Data (NetCDF), Version 1.0. UCAR/NCAR - Earth Observing Laboratory, doi:10.5065/D6BC3WKB, 2013.
UCAR/NCAR: Earth Observing Laboratory, 2005-present, NSF/NCAR G-V HIAPER Aircraft, doi:10.5065/D6DR2SJP, 2015.

Williams, E. R., Zhang, R., Rydock, J.: Mixed-phase microphysics and cloud electrification, J. Atmos. Sci., 48, 2195-2203, 1991. 